\title{
Diagnosis and treatment of deep-vein thrombosis and approach to venous thromboembolism in obstetrics and gynecology
}

\author{
Kadın hastalıkları ve doğum alanında venöz tromboembolizmine yaklaşım ve \\ derin ven trombozu tanı ve tedavisi
}

\author{
K. Mehmet Burgazlı ${ }^{1-2}$, Mehmet Bilgin ${ }^{1}$,Ethem Kavukçu², M. Metin Altay ${ }^{5}$, H. Turhan Özkan ${ }^{3}$, Uğur Coşkun ${ }^{4}$ \\ Hakan Akdere ${ }^{2}$, A. Kubilay Ertan ${ }^{5}$ \\ ${ }^{\prime}$ Clinic of Internal Medicine, Cardiology, Angiology, University Giessen, Giessen, Germany \\ ${ }^{2}$ Department of Internal Medicine, Phlebologie, Medical Center Wuppertal, Wuppertal, Germany \\ ${ }^{3}$ Department of Obstetrics and Gynecology, Okmeydani Training and Research Hospital, Istanbul, Turkey \\ ${ }^{4}$ Clinic of Institute of Cardiology, Istanbul University, Istanbul, Turkey \\ ${ }^{5}$ Department of Obstetrics and Gynecology, Hospital of Leverkusen, Leverkusen, Germany
}

\section{Abstract}

Deep vein thrombosis (DVT) is a common condition in which the approach to its diagnosis has evolved over the years. Currently, an algorithm strategy combining pre-test probability, D-Dimer testing and compression ultrasound imaging allows for safe and convenient investigation of suspected lower-extremity thrombosis. Patients with low pre-test probability and a negative D-Dimer test result can have proximal DVT excluded without the need for diagnostic imaging. The mainstay of treatment of DVT is anticoagulation therapy, whereas interventions such as thrombolysis and placement of inferior vena cava filters are reserved for special situations. The use of low-molecular-weight heparin (LMW) allows for outpatient management of most patients with DVT. The duration of anticoagulation therapy depends on whether the primary event was idiopathic or secondary to a transient risk factor. More research is required to optimally define the factors that predict an increased risk of recurrent DVT to determine which patients can benefit from extended anticoagulant therapy. DVT is also a serious problem in the antenatal and postpartum period of pregnancy. Thromboembolic complications are the leading cause of both maternal and fetal morbidity and mortality. The incidence of venous thromboembolism during normal pregnancy is six-fold higher than in the general female population of childbearing age. The treatment of DVT during pregnancy deserves special mention, since oral anticoagulation therapy is generally avoided during pregnancy because of the teratogenic effects in the first trimester and the risk of fetal intracranial bleeding in the third trimester. LMW heparin is the treatment of choice for DVT during pregnancy. If acute DVT occurs near term, interrupting anticoagulation therapy may be hazardous because of the risk of pulmonary embolism. In this situation, placement of a retrievable inferior vena cava filter must be considered. However, there is no consensus as to what the appropriate dose should be and whether anti-Xa levels need to be monitored.

(J Turkish-German Gynecol Assoc 2011; 12: 168-75)

Key words: Venous thrombosis, heparin, low- molecular- weight: heparin, anticoagulants, partial thromboplastin time, thromboembolism in pregnancy

Received: 30 Junuary, 2011
Accepted: 25 May, 2011
Özet

Derin ven trombozları (DVT), teşhis yaklaşımlarının yıllar içinde büyük değişimler ve gelişmeler gösterdiği sık karşılaşılan bir durumdur. Son zamanlarda, pre-test probabilite, D-Dimer testi ve kompresyon ultrason görüntülemesini kombine eden bir algoritma stratejisi, alt ekstremite trombozlarından şüphelenilen olgularda hem güvenli hem de kullanışlı araştırma imkanı sağlamaktadır. Pre-test probabilitesi düşük, D-Dimer testi negatif olan hastalarda diagnostik görüntülemeye ihtiyaç olmadan, proksimal DVT dışlanabilir. DVT tedavisinin dayanak noktası antikoagülasyon tedavisidir, bununla birlikte tromboliz ve inferiyor vena cava filtreleri gibi girişimler özel durumlara mahsus tedavilerdir. Düşük moleküler ağırlıklı heparin kullanımı DVT'li pekçok hasta için ayaktan tedavi imkanı sağlar. Antikoagülasyon tedavisinin süresi primer olayın idiopatik ya da geçici bir risk faktörüne sekonder oluşuyla ilişkilidir. Tekrarlayan DVT'ler için yüksek risk taşıyan faktörlerin, hangi hastaların uzun süreli antikoagülasyon tedavisinden fayda görebileceğinin optimal olarak belirlenebilmesi için daha çok araştırmaya ihtiyaç vardır. DVT hamileliğin antenatal ve postpartum peryodlarında da ciddi bir problemdir. Tromboembolik komplikasyonlar hem maternal hem de fetal morbidite ve mortalitenin başlıca nedenlerindendir. Normal bir hamilelikte tromboemboli insidansı, doğurganlık yaşlarındaki genel bayan popülasyonuna oranla altı kat daha fazladır. Hamilelik döneminin ilk trimesterindeki teratojenik etkilerinden ve üçüncü timesterde fetal kafa içi kanama riskinden ötürü hamilelikte oral antikoagülan tedaviden kaçınılması nedeniyle, hamilelik döneminin DVT tedavisi özel önem arz eder. Düşük moleküler ağırlıklı heparin hamilelikte DVT tedavisinde tercih edilen tedavidir. Term dönemde akut DVT gelişmişse, pulmoner emboli gelişme riskinden ötürü antikoagulasyon tedavisinin kesilerek ara verilmesi sakıncalı olabilir. Bu durumda erişilebilir inferiyor vena cava filtresi uygulanımı mutlaka dikkate alınmalıdır. Ne var ki, uygun dozun ne olması gerektiği ve anti-Xa seviyelerinin monitorizasyonunun gerekliliği gibi konularda tam bir konsensus mevcut değildir. (J Turkish-German Gynecol Assoc 2011; 12: 168-75)

Anahtar kelimeler: Venöz tromboziz, heparin, düşük moleküler ağırlıklı heparin, antikoagülan, parsiyel tromboplastin zamanı, hamilelikte tromboembolizm

Geliş Tarihi: 30 Ocak 2011 


\section{Definition}

Deep vein thrombosis (DVT) is a systemic disease which can be seen in any location in the venous system. In 1856, Virchow described the major causes of DVT as, venous stasis, hypercoagulation and intimal damage. Factors increasing venous stasis such as; long lasting immobilization, varicosities, obesity, atrial fibrillation, factors increasing hypercoagulability; factor V Leiden mutation, homocystinuria, protein $\mathrm{C}$ or S deficiency, pregnancy, surgery, malignancy, hyperlipidemia and factors increasing the incidence of intimal damage; post operation, intravenous drug abuse, venous catheter insertion cause increased risk for DVT. Clinical findings and symptoms are sometimes insufficient to diagnose a venous thromboembolic event; so some objective tests may be needed for diagnosis. Risk factors, clinical findings, diagnostic methods, complications and treatment modalities of deep vein thrombosis are described in this review. Underdiagnosis of DVT or pulmonary embolisation (PE) causes a high risk of short-term and long-term morbidity and mortality as well as DVT progression, new PE and long-term tissue damage, especially in the lower leg. A postphlebitic syndrome (PPS) occurs in one third of distal DVT, in contrast to one half in cases of proximal DVT (1).

DVT has an estimated annual incidence of 67 per 100000 among the general population $(2,3)$. DVT can lead to complications such as postphlebitic syndrome, pulmonary embolism and death. Despite adequate therapy, $1 \%$ to $8 \%$ of patients developing PE will die, $(4,5)$ whereas others will experience longterm complications such as postphlebitic syndrome (40\%) and chronic thromboembolic pulmonary hypertension (4\%) (6). Although anticoagulant therapy decreases the risk of recurrent thrombosis, the treatment also increases the risk of major hemorrhage. Before 1995, the approach was to image all patients with suspected DVT and to repeat tests 1 week later if results were negative $(7,8)$. This approach was inefficient, since only $10 \%-25 \%$ of patients with suspected DVT were found to actually have the disorder, and results of serial tests were usually negative $(8,9)$. Over the last 10 years, new strategies for diagnosing and treating suspected DVT have been introduced.

\section{Diagnosis}

Single symptoms (edema, pain, sensation of tension, cyanosis and increased protuberance of veins) and classical clinical signs (Homans, Sigg, Payr, Bisgaard, et al.) show a sensitivity of $60-90 \%$ for DVT in outpatients but are not very specific for DVT (9).

\section{Imaging tests}

In recent years the most important diagnostic technique in DVT is Doppler ultrasonography. Compression ultrasonography (CUS) is now the imaging test of choice for diagnosing DVT. Lack of compressibility of a venous segment is the diagnostic criterion used, but the addition of Doppler (including colour flow) can be useful for accurately identifying vessels and confirming the compressibility of a particular segment.

CUS is the method of choice for detection or exclusion of a symptomatic DVT. In contrast to phlebography (gold standard),
CUS has been shown to reach a sensitivity of $95 \%$ and specificity of $94 \%$ for proximal veins (iliofemoral and popliteal veins) (10). Sensitivity for distal veins (paired lower leg veins, calf muscle veins) was lower. This data has to be reviewed with caution because familiarity with the CUS method has increased during recent years and further new comparison between CUS and phlebography are lacking.

In many centres, ultrasound testing is limited to proximal veins (from the common femoral vein caudally to the region of the calf veins where they join the popliteal vein), for which the sensitivity is $97 \%$ for DVT. For DVT in the calf veins, sensitivity is only $73 \%$ (11).

\section{Phlebography}

Ascending contrast venograhy is the traditional gold standard test for diagnosing DVT, but is rarely used in clinical practice because it is labour-intensive, requires injection of contrast dye, and is uncomfortable for the patient.

\section{Clinical prediction rules}

Although none of the symptoms or sings of DVT is diagnostic in isolation, it has been well established that a clinical prediction rule taking into account signs, symptoms and risk factors can accurately be applied to categorize patients as having low, moderate or high probability of DVT. Alternatively, the same rule can be used to categorize cases as "DVT likely" or "DVT unlikely." (12). Over 14 studies have demonstrated the reproducibility of this model (13). Patients who are found to have low pretest probability can have DVT safely excluded on the basis of a single negative ultrasound result (9). Thus, serial ultrasound testing can be avoided in this subgroup of patients. The incorporation of plasma D-Dimer testing into diagnostic algorithms can indentify patients who do not require ultrasonography (12).

\section{D-Dimer testing}

D-Dimers are end products of the proteolysis of fibrin which was created from fibrinogen by thrombin and then cross-linked by factor XIII. D-Dimers function as a marker for fibrinolysis as well as a marker for increased coagulation activity because coagulation leads to simultaneous activation of fibrinolysis to sustain physiological homeostasis. The site where coagulation takes place cannot be displayed by D-Dimers, as markers are increased with any coagulation in the body. Increased D-Dimers are not always a sign of a clinically important clot and coagulation is also an accompanying phenomenon of many pathophysiological states in the body, e.g. inflammation, trauma, operation, pregnancy, cancer or severe bleeding. Due to this fact, proof of elevated D-Dimers cannot be equated with a thromboembolic disease (14).

When the D-Dimer test is compared to the DVT symptom, it is said to be an important test. D-Dimer is a degradation product of a cross-linked fibrin blood clot. Levels of D-Dimer are typically elevated in patients with acute venous thromboembolism, as well as in patients with a variety of nonthrombotic conditions (e.g., recent major surgery, hemorrhage, trauma pregnancy or cancer) (15). D-Dimer assays are, in general, sensitive but nonspecific markers of DVT. The value of the D-Dimer assay resides 
with a negative test result that suggests a lower likelihood of DVT, thus making it a good "rule out" test with the appropriate pretest probability. If applied properly, incorporation of D-Dimer testing into diagnostic algorithms simplifies the management of a patient presenting with suspected DVT.

\section{Diagnostic algorithm for DVT}

Diagnostic algorithms combine single methods to an examination sequence which is able to establish a reliable basis for therapeutic decisions with the least effort. The first steps in the examination sequence have a high sensitivity whereas the later steps have a high specificity (16). Selection of method includes special test characteristics, their local availability and their validity. Above mentioned methods (clinical prediction rules, D-Dimer testing, CUS and phlebography) can be combined to a logical algorithm. Figure 1 displays a recommendation. A diagnostic test for thrombophilia during an acute DVT is rarely indicated as the results will have no impact on the immediate therapeutic decision (17-19). Only in a very few cases can results of thrombophilia diagnostic influence the duration of anticoagulation therapy. In an acute descending thrombosis, local reasons for thrombosis shall be exploited. Reasons could be a tumor or anatomical variants and anomalies in vein formation in young patients.In cancer diseases, there is an increased rate of venous thromboembolism, and around $15 \%$ of cases with an acute DVT have a previous cancer diagnosis at the time of DVT diagnosis. In the case of an idiopathic venous thrombosis, cancer diagnostic work-up is indicated because of its high coincidence, especially after the fifth decade of life (16).

Patients with symptoms compatible with DVT should initially have a determination of pretest probability, using an established prediction model (Figure 2). It is important to take the history first and carry out a physical examination. The model should be applied only if DVT remains a diagnostic possibility. After the clinical pretest probability is determined, a D-Dimer test should be performed. We are using a scoring system for suspected DVT as described in the reference number 20. In our centre, a score of less than 1 (unlikely DVT) by our current model, which incorporates previously documented DVT as a new variable, is sufficient to exclude DVT in patients with a negative moderately sensitive D-Dimer level without ultrasound imaging (20). No D-Dimer assay should be used to exclude DVT in patients having high pretest probability. Clinical assessment and D-Dimer testing have the further advantage of enabling the management of patients with suspected DVT, presented at times when radiographic imaging is not routinely available. Patients with a moderate or high clinical suspicion of DVT may receive an injection of LMW heparin in doses designed to treat acute DVT. Diagnostic imaging can then be arranged on a more elective basis the following day. Since LMW heparin therapy is safe and effective for patients with proven DVT, it provides adequate protection for patients with a suspicion of DVT $(20,21)$. For patients with low risk of DVT (as determined either by means of a clinical diagnostic model or sensitive D-Dimer test), diagnostic imaging may be delayed for 12-24 hours without the need for anticoagulant coverage (9). The clinical prediction rule was developed and validated pre- dominantly in studies involving outpatients. Pregnant women were not included in these studies. Furthermore, the utility of the D-Dimer test in patients admitted to hospital often with other accompanying comorbidities (e.g., infection, postoperative symptoms) is less, since the D-Dimer assay rarely yields negative results. Finally, if DVT is not a diagnostic possibility, D-Dimer test should not be done, because a positive result may cause the clinician to unnecessarily investigate for DVT rather than investigating the actual cause of leg symptoms. The ideal strategy for diagnosing DVT in patients with previous DVT in the symptomatic leg is still debated. However, results of a randomized trial demonstrated the safety of combining clinical probability, D-Dimer and ultrasound imaging in these patients. The biggest concern with this patient population is false-positive ultrasound results. It is helpful to recognise that acute DVT is usually occlusive, not echogenic, and it tends to be continuous. When it reveals thrombosis that is echogenic, nonocclusive or discontinuous, then chronic DVT should be considered. Serial testing or venography can help to clarify the issue. Previous ultrasound results are helpful for comparison, when available. An increase in clot diameter by $4 \mathrm{~mm}$ suggests recurrence, as does extension (22).

Phlebography is not generally available anymore. Due to this lack of availability, qualities of results are sometimes not satisfying. However, in an idealistic case, phlebography is able to detect very small clots, evaluate the status of calf muscle veins, display collateral cycles in total and exclude a thrombosis with high certainty (23-25). Another advantage of phlebography is its objectivity and its comprehensive documentation, which also displays the total anatomy. Disadvantages of phlebography are invasiveness, radiation exposure, possible allergic reactions to the contrast medium and its lack of information on differential diagnosis compared to ultrasonography. Due to these disadvantages, the first line diagnostic tool is ultrasonography. Phlebography is used as a second line when ultrasonography is not able to reliably detect the case of recurrent thrombosis and during preparation of restitution surgery.

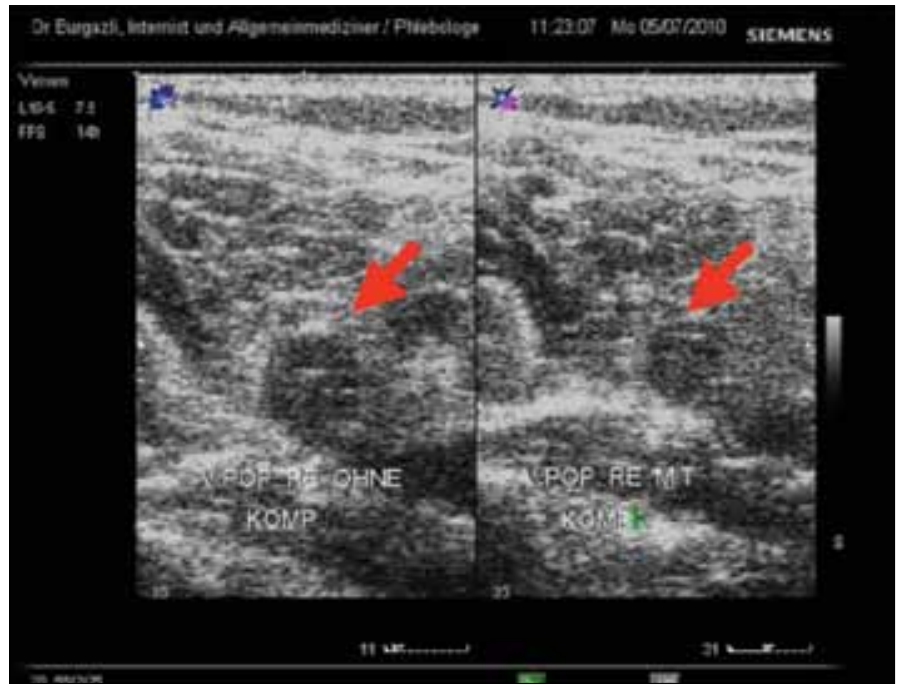

Figure 1. Image with and without compression of right V. popliteal Deep Vein Thrombosis with B mode ultrasonography 


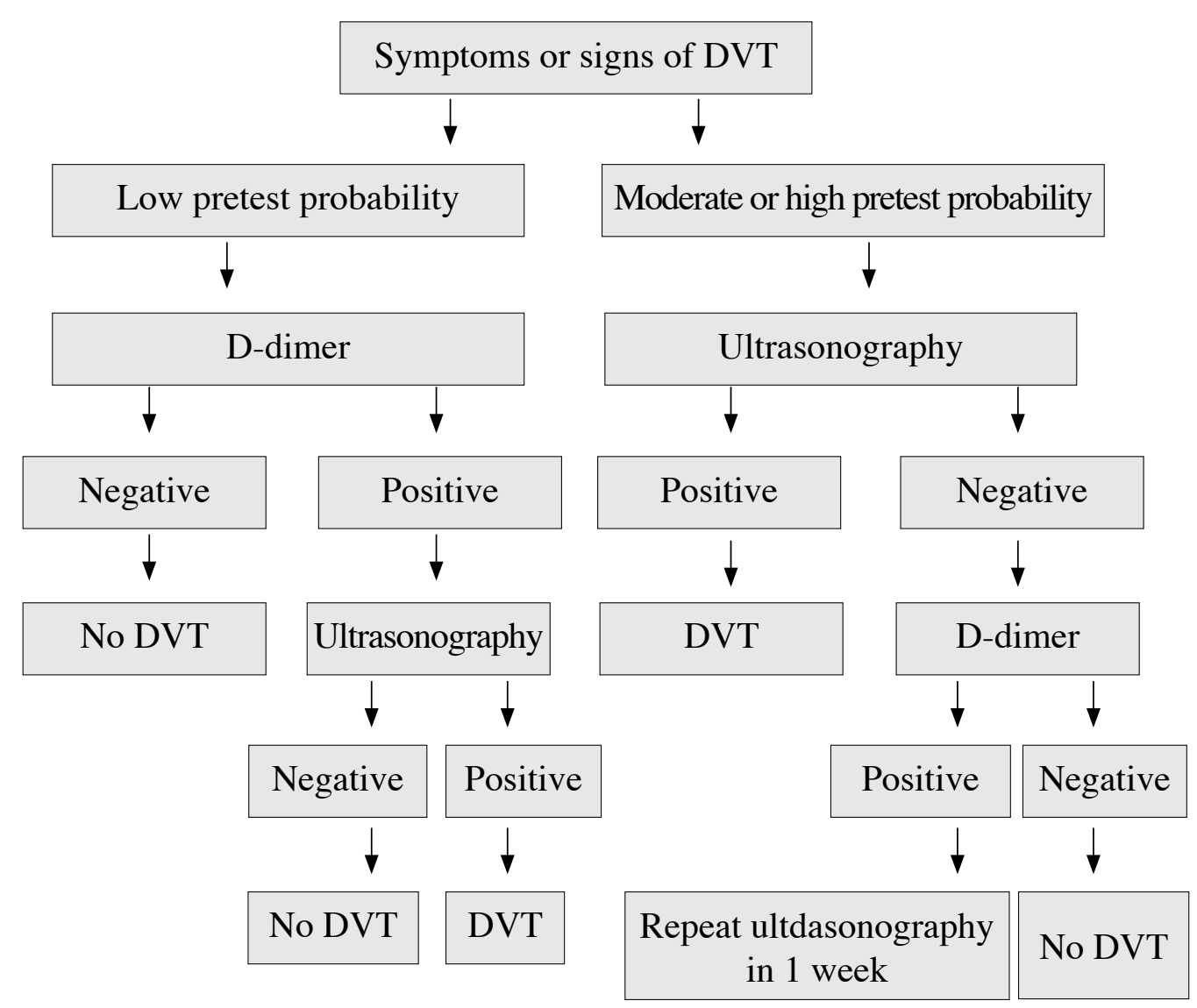

Figure 1. Diagnostic algorithm using D-Dimer testing and ultrasound imaging with suspected DVT

Most diagnostic and treatment studies of DVT have excluded pregnant women, and therefore it is difficult to formulate evidence-based recommendations for this population. Although serial impedance plethysmography has been demonstrated to safely rule out DVT (26), it is not widely used. Results of a small pilot study suggest that a strategy involving serial CUS combined with a moderately sensitive D-Dimer assay is effective in excluding DVT in pregnant women (27). D-Dimer levels are often positive in the later stages of pregnancy, $(28,29)$ lowering the utility of this test to rule out DVT. Research to develop algorithms to diagnose DVT in pregnant women is ongoing. D-Dimer levels show higher increases in preeclampsia-eclampsia, but these increases are not related with adverse pregnancy outcomes (30).

\section{Treatment}

The aim of DVT treatment is to avoid PE and postphlebitic syndrome. Anticoagulation with LMW heparins in therapeutic dosage should start immediately after diagnosis. In case of severe renal failure (creatinin clearance $\leq 30 \mathrm{ml} / \mathrm{min}$ ) or during vascular angioplasty procedure, non-fractionated heparin is the medication of choice. LMW heparins cause significantly less probability of a heparin-induced thrombocytopenia (HIT) type 2 than non-fractionated heparins. In case of a contraindication for heparin (e.g. because of previous HIT type 2) LMW heparins can be used instead heparin.

Initial treatment of DVT with parenteral anticoagulation (heparin or LMW heparin) should be performed for at least 5 days combined with the administration of a vitamin $\mathrm{K}$ antagonist therapy between day one and two after diagnosis until an INR $>2.0$ for at least 24 hours.

A compression therapy with compression stockings is reasonable because it is able to decrease frequency and severity of the postphlebitic syndrome. Long-term effects show a $50 \%$ decreased incidence of the postphlebitic syndrome at compression pressures between 30 to $40 \mathrm{mmHg}$.

The goal of the therapy for lower-extremity DVT is to prevent the extension of the thrombus and PE in the short-term and to prevent recurrent events in the long-term. Based on extensive research evaluating the risk of recurrent DVT, guidelines have been established for the duration of anticoagulation therapy. LMW heparin therapy has changed the landscape of treatment of DVT by enabling home treatment and by providing an alternative long-term anticoagulant in cases where warfarin is less effective or contraindicated. The following applies in the treatment of proximal lower -extremity DVT, since there is little evidence to formulate recommendations for isolated DVT in calf veins. 
Cancer patients with thrombosis should be treated with LMW heparin for 3 to 6 months instead of vitamin $\mathrm{K}$ antagonist. Type and duration of the following anticoagulation therapy depends on the cancer disease activity and the bleeding risk. Secondary prevention with vitamin $\mathrm{K}$ antagonists is complicated by interactions between vitamin $\mathrm{K}$ antagonists and chemotherapeutical cancer treatment, by liver dysfunction, transient thrombocytopenia and accompanying infections and their treatment. Due to these interactions, LMW heparins appear to have a greater benefit. Further, it is reported in randomized studies that venous thromboembolism risk is halved by LMW heparins in comparison to vitamin $\mathrm{K}$ antagonist without an increased bleeding risk (31).

\section{Initial choice of anticoagulation}

Initial therapy must involve therapeutic doses of either unfractionated heparin or LMW heparin. Initial treatment with oral anticoagulant therapy alone is unacceptable (32). The ease of administration and efficacy of LMW heparin makes it the preferred choice of anticoagulant, whether given on an outpatient or inpatient basis. In a meta-analysis comparing the effectiveness of LMW heparin at a fixed dose with unfractionated heparin at an adjusted dose, significantly fewer deaths, major hemorrhage and recurrent venous thromboembolism were reported to occur with LMW heparin (33).

Thus, the current standard of care is to administer weightadjusted LMW heparin once daily, for 5-7 days as the initial treatment. It remains unknown whether it is better to administer LMW heparin once or twice daily. The results of a meta-analysis suggested that hemorrhage and recurrent venous thromboembolism were less likely to occur with twice daily dosing, but the $95 \%$ confidence interval on the odds ratio crossed 1.0 (34). Since LMW heparin is predominantly excreted by the kidneys, unfractionated heparin should be used in patients with significant renal dysfunction. A newer agent is the synthetic pentasaccharide fondaparinux, which is at least as effective and safe as LMW heparin in the treatment of DVT (35). Fondaparinux can be considered as an alternative agent for the treatment of DVT with the added benefit that, to date, heparin-induced thrombocytopenia has not been reported with this agent.

\section{Long-term treatment}

The long-term treatment in DVT prevents new attacks. For the majority of patients with DVT, oral therapy with vitamin K antagonists (e.g. warfarin) is very effective for long-term prevention of recurrent thrombosis (36). Although the initial treatment of DVT is similar for most patients, the duration of long-term treatment varies depending on the perceived risk of recurrent DVT. The risk can be classified into the following 5 categories:

- First proximal DVT occurs in the context of a transient risk factor (e.g. surgery or trauma).In this situation, the risk of recurrence is very low and a limited duration of therapy (3 months) is adequate $(37,38)$.

- First DVT occurs in the context of active malignant disease, which is an ongoing risk factor. Patients with malignant disease have a higher incidence of recurrent thrombosis and bleeding complications while receiving oral anticoagulation therapy following a first thrombotic event $(39,40)$. This is probably due to the prothrombotic state associated with cancer and to the difficulty of managing oral anticoagulant therapy with concomitant drugs, erratic oral intake and liver dysfunction. Researchers with the CLOT trial (31) have shown that long-term anticoagulation therapy with LMW heparin is more effective than warfarin in preventing recurrent venous thrombosis without a statistically significant increase in bleeding risk.

- First DVT occurs in the context of a thrombophilic defect. These defects include factor $\mathrm{V}$ Leiden, prothrombin gene mutation, deficiencies in protein $\mathrm{C}$, protein $\mathrm{S}$ and antithrombin, increased factor VIII levels, hyperhomocysteinemia and elevated antiphospholipid antibody levels. Many of these defects are associated with an increased risk of first DVT. Patients with persistently elevated antiphospholipid antibody levels determined by either ELISA or clotting assays have a 2 -fold higher relative risk of recurrence within 4 years after stopping anticoagulation therapy for a first DVT than those without this thrombophilia (41).

- Recurrent DVT. After a second recurrence of DVT, the risk of further thromboembolic events following the discontinuation of anticoagulation therapy is felt to be excessive if only 6 months of oral anticoagulation therapy is administered (42).

- First DVT occurs in the absence of temporary or identifiable on going risk factors for thrombosis (idiopathic). Six months is considered a minimum duration for anticoagulation therapy in these patients, while continuing for longer is effective in preventing thrombosis. However, the risk of recurrent venous thromboembolism in the first year after stopping anticoagulation therapy is about $10 \%$, regardless of when the therapy is stopped after 6 months (43).

In addition to the thrombophilic defects described previously, two factors have been shown to increase the risk of recurrence after stopping anticoagulation therapy. Residual thrombosis (seen on a follow-up ultrasound scan 3 months after an initial event) increases the risk of recurrence (odds ratio 2, 4) (44). One-third of the recurrences occur in the initially unaffected leg, which suggests that residual DVT is a marker of systemic hypercoagulability In one study, elevated D-Dimer levels 1 month after stopping anticoagulation therapy were associated with an elevated risk of recurrent thrombosis in all but cancerrelated thrombosis (45).

\section{Intensity of anticoagulation therapy}

The standard intensity of oral anticoagulation therapy is an international normalized ratio (INR) of 2 to 3 . In patients who have antiphospholipid antibody-related thrombosis, it has long been considered that higher intensity anticoagulation therapy is needed to prevent recurrence (46). However, results of two randomized controlled trials showed that standard anticoagulation therapy is as effective as high-intensity treatment, even in the subgroup of patients $(47,48)$. Therefore, high-intensity anticoagulation therapy is not recommended in any patient with DVT: Maintaining good INR control will decrease the risk of postphlebitic syndrome (49). There has also been debate on the usefulness of long-term low-intensity anticoagulation therapy (INR 
1.5-1.9) in preventing recurrent thrombosis, while reducing the risk of bleeding. A large randomized trial has shown that lowintensity anticoagulation therapy is less effective than standard anticoagulation therapy in preventing recurrent thrombosis and does not lower the risk of bleeding (50). Therefore, lowintensity therapy is not recommended.

\section{Upper-extremity DVTs}

Upper-extremity DVTs can be subdivided into catheter- and noncatheter-related thrombosis. There is a risk of pulmonary embolism with this condition, and therefore treatment with anticoagulation therapy is generally recommended.

\section{Other interventions}

Although anticoagulation therapy is the mainstay of treatment of DVT, thrombolysis and placement of an inferior vena cava filter are the two interventions worthy of mention.

The addition of systemic thrombolysis to standard anticoagulation therapy leads to earlier patency of an occluded vein, however, it does not affect the rate of PE. There is a definite increase in the risk of major hemorrhage; including intracranial hemorrhage, with thrombolysis. Catheter-directed thrombolysis has also been associated with increased risk of bleeding complications. It is unclear whether the earlier recanalization observed with thrombolysis translates into lower rates of the postthrombotic syndrome in the long term $(14,51)$. Thrombolysis is not generally recommended except in the case of massive DVT, which leads to phlegmasia cerulean dolens and threatened limb loss.

Placement of an inferior vena cava filter in addition to anticoagulation therapy has not been found to prolong survival among patients with DVT: While preventing PE, insertion of a filter increases the risk of recurrent DVT $(52,53)$.

A retrievable filter is indicated when there is a contraindication to anticoagulation therapy (recent hemorrhage, impending surgery) in patients with newly diagnosed proximal DVT. It remains to be determined whether a retrievable filter in patients at higher risk of death (e.g. limited cardiopulmonary reserve) will lead to a reduction in pulmonary embolism-related death. Postphlebitic syndrome is a frequent complication of DVT and a major public health issue that has been underresearched. It is unclear who is at highest risk and how best to prevent and treat this complication.

\section{Thrombolytic therapy and surgical embolectomy}

Compared with heparin, thrombolysis improves vein patency and reduces the risk of post-thrombotic syndrome, but increases the risk of bleeding, and there is no evidence of a net clinical benefit. Thrombolysis and surgical embolectomy have been used as a limb-saving therapy in patients with extensive proximal DVT and circulatory compromise or venous gangrene (16).

\section{Vena cava filter}

Inferior vena cava filters are indicated to prevent $\mathrm{PE}$ in patients with DVT who experience embolism despite adequate anticoagulation. Filters do not obviate the need for anticoagulation because they are associated with an increased risk of recurrent DVT. However, the optimal duration of anticoagulation which is deemed safe is uncertain (16).

\section{Deep vein thrombosis in pregnancy}

Deep vein thrombosis (DVT) is a serious problem in the antenatal and postpartum periods of pregnancy. Thromboembolic complications are the leading cause of both maternal and fetal morbidity and mortality. The incidence of venous thromboembolism during normal pregnancy is six-fold higher than in the general female population of childbearing age (26).

\section{Pathophysiology}

During normal pregnancy there are substantial changes in the hemostatic system, many of which are procoagulant and are thought to be in preparation for the hemostatic challenge of delivery. Normal hemostasis requires a balance between coagulation and fibrinolysis to maintain the integrity of the vasculature. The complex physiological changes evident during pregnancy appear to ensure a constant coagulation-fibrinolysis balance. The balance is maintained, at least partially, by an increase in fibrinolytic activity, but decreases in other factors such as factor XI, and monocyte tissue factor expression may also serve to counter- balance procoagulation changes.

\section{Anticoagulant therapy}

Anticoagulant therapy is the standard treatment for DVT but is mostly used in non-pregnant patients. In pregnancy, unfractionated heparin (UFH) and LMW heparin are commonly used. Warfarin therapy is generally avoided in pregnancy because of its fetal toxicity.

LMW heparin has been shown to be as safe and effective as UFH for the treatment of acute venous thrombosis and non lifethreatening PE. LMW heparins are anticoagulants of choice, when a rapid anticoagulant effect is required. LMW heparin has several advantages over UFH, including a longer plasma half life, higher bioavailability and a predictable dose response, which enable once or twice-daily dosing, and a more convenient route of administration (16).

The non hemorhagic adverse effects of UFH include heparininduced thrombocytopenia (HIT) and osteoporosis, which is less with LMW heparin. HIT is a life threatening condition that is associated with the development of antibodies, activating platelets and the coagulation system in the presence of UFH or LMW heparin (54).

The safety of LMW heparin administration for the mother and fetus has not been well established. Enoxaparin has been shown not to cross the placenta and therefore appears safe for the fetus. It is uncertain whether weight adjusted dosage regimens without laboratory monitoring can be used in pregnant women (16)

\section{Diagnosis}

Therapy is usually initiated following a clinical diagnosis of venous thrombosis. Therapy is continued while awaiting diagnostic tests such as Doppler ultrasound (compression or duplex 


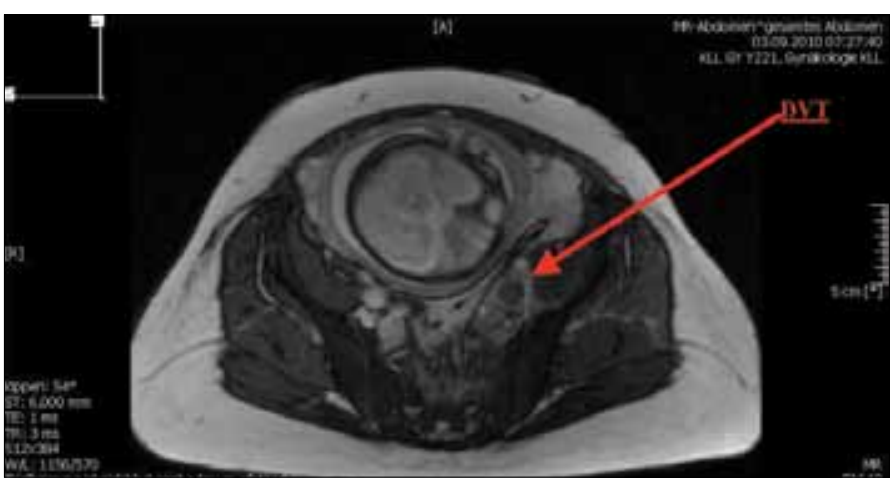

Figure 3. MRI image showing the DVT in pregnancy

scanning) and MRI (Figure 3), which are the best diagnostic methods in pregnancy. D-Dimer, a screening test for DVT with high negative predictive value, is used in non- pregnant patients. Its use in pregnancy is still controversial.

MR-Phlebography is a promising alternative especially in the proximal thigh and pelvis area. Diagnosis of a venous thrombosis during pregnancy should be interdisciplinary. So far there is no algorithm tested for thrombosis during pregnancy but any suspicion should be traced up to exclusion (55).

\section{Mode of administration of anticoagulant}

The mode of administration influences the effectiveness of anticoagulant therapy, UFH is subsequently administered subcutaneously. Intravenous administration has a more rapid onset and is therapeutically more reliable than subcutaneous administration. However, intravenous administration is difficult to maintain on a long-term basis.

Subcutaneous injection of LMW heparin leads to less pain due to a smaller injection volume. However, the patient may still suffer from bruises.

Warfarin therapy is easier to administer but is usually avoided in pregnancy due to its teratogenic effect.

\section{Monitoring of anticoagulant therapy}

Patients receiving anticoagulant therapy are monitored to observe the therapeutic efficacy as well as side effects. Hemorrhagic complications are clinically assessed. Patients receiving UFH, LMW heparin and warfarin are routinely monitored with activated partial thromboplastin time (APTT), antiXa activity and INR respectively. Platelet count is occasionally assessed especially in patients receiving UFH and LMW heparin. Patient knowledge of proper injection technique, prevention and recognition of complications should be considered during follow up.

\section{Conflict of interest}

No conflict of interest was declared by the authors.

\section{References}

1. Barritt DW, Jordan SC. Anticoagulant drugs the treatment of pulmonary embolism.A controlled trial. Lancet 1960; 1: 1309-12. [CrossRef]

2. White RH. The epidemiology of venous thromboembolism. Circulation 2003; 107: I4-8. [CrossRef]
3. Silverstein MD, Heit JA, Mohr DN, Petterson TM, O'Fallon WM, Melton LJ 3rd. Trends in the incidence of deep vein thrombosis and pulmonary embolism: a 25 -year population-based study. Arch Intern Med 1998; 158: 585-93.

4. Hirsh J, Bates SM. Prognosis in acute pulmonary embolism. Lancet 1999; 353: 1375-8. [CrossRef]

5. Prandoni P, Lensing AWA, Prins M. Long-term outcomes after deep venous thrombosis of the lower extremeties . Vasc Med 1998; 3: 57-60 [CrossRef]

6. Kahn SR,Ginsberg JS. Relationsship between deep venous thrombosis and the postthrombotic syndrome. Arch Intern Med 2004; 164: 17-26. [CrossRef]

7. Kahn SR,Ginsberg JS. Relationsship between deep venous thrombosis and the postthrombotic syndrome. Arch Intern Med 2004; 164: 17-26. [CrossRef]

8. Cogo A, Lensing AW, Koopman MM, Piovella F, Siragusa S, Wells PS, et al. Compression ultrasonography for diagnostic management of patients with clinically suspected deep vein thrombosis: prospective cohort study. BMJ 1998; 316: 17-20. [CrossRef]

9. Wells PS, Anderson DR, Bormanis J, Guy F, Mitchell M, Gray L, et al. Value assessment of pretest probability of deep-vein thrombosis in clinical management. Lancet 1997; 350: 1795-8. [CrossRef]

10. Goodarce S, Sampson F, Thomas S, van Beek E, Sutton A. Systematic review and meta-analysis of the diagnostic accuracy of ultrasonography for deep vein thrombosis. BMC Med Imaging 2005; 5: 6 .

11. Kearon C, Julian JA, Newman TE, Ginsberg JS. Noninvasive diagnosis of deep vein thrombosis. Ann Intern Med 1998; 128: 663-77.

12. Dalen JE. Should patients with venous thromboembolism be screened for thrombophilia? Am J Med 2008; 121: 458-63. [CrossRef]

13. Wells PS, Owen C, Doucette S, Fergusson D, Tran H. Does this patient have deep vein thrombosis? JAMA 2006; 295: 199-207. [CrossRef]

14. Forster A, Wells P. Tissue plasminogen activator for the treatment of deep venous thrombosis of the lower extremity: a systematic review. Chest 2001; 119: 572-9. [CrossRef]

15. Kelly J, Rudd A, Lewis RR, Hunt BJ. Plasma D- dimmers in the diagnosis of venous thromboembolism. Arch Intern Med 2002; 162: 747-56. [CrossRef]

16. Wells PS. Integrated strategies for the diagnosis of venous thromboembolism. J Thromb Haemost 2007; 1: 41-50. [CrossRef]

17. Cohn D, Vansenne F, de borgie C Middeldorp S. Thrombophilia testing for prevention of recurrent venous thromboembolism. Cochrane Database Syst Rev 2009; CD007069.

18. Wells PS, Owen C, Doucette S, et al. Does this patient have deep vein thrombosis? JAMA 2006; 295: 199-207. [CrossRef]

19. Simpson EL, Stevenson MD, Rawdin A Papaioannou D. Thrombophilia testing in people with venous thromboembolism: Systematic review and cost-effectiveness analysis. Health Technol Assess 2009; 13: 1-91.

20. Anderson DR, Kovacs MJ, Kovacs G, Stiell I, Mitchell M, Khoury V, et al. Combined use of clinical assessment and D-dimer to improve the management of patients presenting to the emergency department with suspected deep- vein thrombosis (the EDITED Study). J Thromb Haemost 2003; 1: 645-51. [CrossRef]

21. Bauld DL., Kovacs MJ. Dalteparin in emergency patients to prevent admission prior to investigation for venous thromboembolism. Am J Emerg Med 1999; 17: 11-4 [CrossRef]

22. Heijboer H, Jongbloets LM, Büller HR, Lensing AW, ten Cate JW. Clinical utility of real-time compression ultrasonography for diagnostic management of patients with recurrent venous thrombosis. Acta Rad 1992; 33: 297-300. [CrossRef]

23. Hach W, Hach-Wunderle V. Phlebography and sonography of the veins. Berlin-Heidelberg-New York, Springer, 1997. [CrossRef]

24. Hach W, Hach-Wunderle V. Die phlebographische Untersuchung der soleus- und Gastrocnemiusvenen. Gefässchirurgie 2002; 7: 31-8. [CrossRef] 
25. Hull R, Hirsh J, Sackett DL, Taylor DW, Carter C, Turpie AG, et al. Clincal validity of a negative venogram in patients with clinically suspected venous thrombosis. Circulation 1981; 64: 622-5. [CrossRef]

26. Hull RD,Raskob GE, Carter CJ. Serial impedance plethysmography in pregnant patients with clinically suspected deep-vein thrombosis Clinical validity of negative findings. Ann Intern Med 1190; 112: 663-7.

27. Chan WS, Chunilal SD, Lee AY, et al. Diagnosis of deep vein thrombosis during pregnancy;a pilot study evaluating the role of D- dimer and compression leg ultrasound during pregnancy. Blood 2002; 100: 275. [CrossRef]

28. Epiney M, Boehlen F, Boulvain M, Reber G, Antonelli E, Morales M, et al. D-dimer levels during delivery and the postpartum. J Thromb haemost 2005; 3: 268-71.

29. Eichinger S. D-dimer testing in pregnancy. Pathophysiol haemost thromb 2003; 33: 327-9. [CrossRef]

30. Royle G, Barry CL, Blacklock H, Lake Y. D-D dimers: a poor correlate of PPIH and subsequent outcomes. Int J Gynaecol Obstet. 1998; 62: 37-42. [CrossRef]

31. Lee AY, Levine MN, Baker RI, Bowden C, Kakkar AK, Prins M, et al.Low-molecular -weight heparin versus Coumadin for prevention of recurrent venous thromboembolism in patients with cancer. $\mathrm{N}$ Engl J Med 2003; 349: 146-53.

32. Brandjes DPM, Heijboer H, Buller HR, et al. Acenocoumarol and heparin compared with acenocoumarol alone in the initial treatment of proximal-vein thrombosis. N Engl J Med 1992; 327: 1485-9. [CrossRef]

33. van Dongen CJ, van den Belt AG, Prins MH, Lensing AW. Fixed dose subcutaneous low molecular weight heparins versus adjusted dose unfractionated heparin for venous thromboembolism (review). Cochrane Datebase Syst Rev. 2004; 18: CD001100. [CrossRef]

34. Van Dongen CJ,Mac Gillavry MR, Prins MH. Once versus twice daily LMWH for the initial treatment of venous thromboeembolism (review). Cochrane Database Syst Rev. 2003; CD003074. [CrossRef]

35. Büller HR, Davidson BL, Decousus H, Gallus A, Gent M, Piovella $\mathrm{F}$, et al. Matisse Investigators. Fondaparinux or enoxaparin for the initial treatment of symptomatic deep vein thrombosis. A randomized trial.Ann Intern Med 2004; 140: 867-73.

36. Hull R, Hirsh J, Jay R, Carter C, England C, Gent M, et al. Different intensities or oral anticoagulant therapy in the treatment of proximal-vein thrombosis. N Engl J Med 1982; 307: 1676-81. [CrossRef]

37. Levine MN, Hirsh J, Gent M, Turpie AG, Weitz J, Ginsberg J, et al. Optimal duration of oral anticoagulation therapy: a randomized trial comparing four weeks with three months of Warfarin in patients with proximal deep vein thrombosis. Thromb Haemost 1995; 74: 606-11.

38. Schulman S, Rhedin AS, Lindmarker P, Carlsson A, Lärfars G, Nicol P, et al. comparison of six weeks with six months of oral anticoagulant therapy after a frist episode of venous thromboembolism:Duration of Anticoagulation Trial Study Group. N Engl J Med 1995; 332: 1661-5. [CrossRef]

39. Hansson PO,Sorbo J, Eriksson H. Recurrent venous thrombobolism after deep vein thrombosis: incidence and risk factors. Arch Intern Med 2000; 160: 769-74. [CrossRef]
40. Prandoni P, lensing A, Piccioli A, et al.Recurrent venous thromboembolism and bleeding complications during anticoagulation treatment in patients with cancer and venous thrombosis. Blood 2002; 100: 3484-8. [CrossRef]

41. De Stefano V, Martinelli I, Mannucci PM, et al. The risk of recurrent deep venous thrombosis among heterozygous carriers of both factor V Leiden and the G20210A prothrombin mutation. N Engl J Med 1999; 341: 801-6. [CrossRef]

42. Schulman S, Granqvist S, Holmström M, Carlsson A, Lindmarker $\mathrm{P}$, Nicol P, et al. The durationof anticoagulation after a second episode of venous thromboembolism. N Engl J Med 1997; 336: 393-8. [CrossRef]

43. Ost D, Tepper J, Mihara H, Lander O, Heinzer R, Fein A. Duration of anticoagulation following venous thromboembolism: A metaanalysis. JAMA 2005; 294: 706-15. [CrossRef]

44. Prandoni P, Lensing AW, Prins MH, Bernardi E, Marchiori A, Bagatella P, et al. Residual thrombosis as a predicitive factor of recurrent venous thrombosis. Ann Intern Med 2002; 137: 955-60.

45. Cushman M, Folsom AR, Wang L, Aleksic N, Rosamond WD, Tracy $\mathrm{RP}$, et al. Fibrin fragment D-dimer and the risk of future venous thrombosis. Blood 2003; 101: 1243-8. [CrossRef]

46. Khamashta MA, Cuadrado MJ, Mujic F, Taub NA, Hunt BJ, Hughes GR. The managmentofthrombosis in the antiphospholipid-antibody syndrome.N Engl J Med 1995; 332: 993-7. [CrossRef]

47. Crowther MA, Ginsberg JS, Julian J, Denburg J, Hirsh J, Douketis J, et al. A comparison oft wo intensities of warfarin fort he prevention of recurrent thrombosis in patients with the antiphospholipid antibody syndrome N Engl J Med 2003; 349: 1133-8. [CrossRef]

48. Finazzi G, Marchioli R, Brancaccio V, Schinco P, Wisloff F, Musial $\mathrm{J}$, et al. A randomized clinical trial of high-intensity warfarin vs. conventional antithrombotic therapy for the prevention of recurrent thrombosis in patients with the antiphospholipid syndrome (WAPS). J Thromb Haemost 2005; 3: 848-53. [CrossRef]

49. van Dongen CJ, Prandoni P, Frulla M, Marchiori A, Prins MH, Hutten BA. Relation between quality of anticoagulant treatment and the development of the postthrombotic syndrome. J Thromb Haemost 2005; 3: 939-42. [CrossRef]

50. Kearon C, Ginsberg JS, Kovacs MJ, Anderson DR, Wells P, Julian $\mathrm{JA}$, et al. Comparison of low-intensity warfin therapy with conventional -intensity warfin therapy for long-term prevention of recurrent venous thromboembolism .N Engl J Med 2003; 349: 631-9.

51. Wells PS, Forster AJ. Thrombolysis in deep vein thrombosis: Is there still an indication? Thromb Haemost 2001; 86: 499-508.

52. Decousus H, Leizorovicz A, Parent F, Page Y, Tardy B, Girard P, et al. A clinical trial of vena cava filters in the prevention of pulmonary embolism in patients with proximal deep-vein thrombosis. $\mathrm{N}$ Enl $\mathrm{J}$ Med 1998; 338: 409-15. [CrossRef]

53. PREPIC Study Group. Eight-year follow-up of patients with permanent vena cava filters in the prevention of pulmonary embolism: the PREPIC (Prevention du Risque dÉmbolie Pulmonaire par Interruption Cave ) randomized study. Circulation 2005; 112: 416-22. [CrossRef]

54. Greer I, Hunt BJ. Low molecular weight heparinin pregany: current issues.Br J Haematol 2005; 128: 593-601. [CrossRef]

55. Ginsberg JS, Bates SM. Management of venous thromboembolism during pregnancy. J Thromb Haemost 2003; 1435-42. [CrossRef] 